\title{
Investment in the Belt and Road to Promote the Expansion of International Financial Markets
}

\author{
Huang Xingrui ${ }^{1, *}$
}

\author{
${ }^{1}$ Shihezi No. 1 Middle School, Shihezi, Xinjiang 832000 \\ *Corresponding author Email: 837940875@qq.com
}

\begin{abstract}
The global financial impact of Chinese overseas investment, market constraints and hostile risk management. Understanding China's important role in the international community. Belt and Road investment promotes the expansion of financial market scale, but also brings some disadvantages. The Belt and Road ' has gradually formed a major idea of regional cooperation from line to piece. It takes the project as the carrier, focuses on the comprehensive transportation corridor as the development space, connects the traffic infrastructure along the line and the central urban agglomeration, constructs the economic corridor, promotes regional economic integration, and finally realizes the synchronous development of regional economy and society.
\end{abstract}

Keywords: the Belt and Road, market strategy, market constraints

\section{THE DIFFICULTIES AND RISKS FACED BY OVERSEAS INVESTMENT ALONG THE BELT AND ROAD IN CHINA}

In international trade, the global financial impact, market constraints and hostile risk management of overseas investment along the Belt and Road in China. China ' s Belt and Road overseas investment mainly affects the international financial market from four aspects : scale, structure, risk distribution and regulatory mechanism. The connectivity and infrastructure investment of countries along the road promote the formation and development of regional investment facilitation and investment cooperation organizations along the road, and promote the scale expansion of international financial markets from the investment level. Belt and Road investment promotes the expansion of financial market scale, but also brings some disadvantages. The Belt and Road ' has gradually formed a major idea of regional cooperation from line to piece. It takes the project as the carrier, focuses on the comprehensive transportation corridor as the development space, connects the traffic infrastructure along the line and the central urban agglomeration, constructs the economic corridor, promotes regional economic integration, and finally realizes the synchronous development of regional economy and society. The Belt and Road Initiative will strive to achieve better regional infrastructure, further enhance the level of investment and trade facilitation, and closer economic ties. The specific impact is divided into four aspects : Impact on the bond market : the bonds of the Belt and Road mainly include government bonds issued by government agencies in countries ( regions ) along the Belt and Road on the Shanghai Stock Exchange, corporate bonds issued by enterprises and financial institutions in countries ( regions ) along the Belt and Road on the Shanghai Stock Exchange, and corporate bonds issued by domestic and foreign enterprises on the Shanghai Stock Exchange for the construction of the Belt and Road. Asset-backed securities and other bond varieties used for the ' Belt and Road ' initiative are listed on the exchange or listed for transfer, with reference to this Circular. It is expected that the scale of ' the Belt and Road ' bonds will rise steadily. This is of great significance to China 's economy and finance, helping to create a new pattern of China 's economy and promoting the common prosperity of financial markets in countries and regions along the route. Impact on the stock market : when the new global strategy of ' One Belt and One Road ' is put into effect, the A-share market will enter a stage of systematic market competition where ' China Creation ' and ' Made in China ' are flying. Institutions are more pessimistic about PPI, the leading indicator of the industrial economy. Most analysts expect the decline to exceed $2 \%$. Among them, Gao Qian believes that last month PPI decline will reach $2.30 \%$, Haitong Securities analyst Jiang Chao is expected to reach $2.20 \%$. A fund 
strategy analyst said that although the foreign trade data in October 2014 were very strong, the macroeconomic data in the fourth quarter would still be not good, but the impact on the stock market was getting smaller and smaller. In fact, the recent short selling seems to have forgotten the fluctuation of macro data. On October 21,2014, the National Bureau of Statistics released the third quarter economic data, the GDP growth rate fell to $7.3 \%$ in a single quarter. Although the Shanghai Composite Index continued to appear five negative lines, it recovered in less than two trading days. On 1 November 2014, the Bureau of Statistics released the PMI for October 2014, the lowest index for the last five months of 2014. [6] The trend is consistent with HSBC PMI, but A shares remain strong. [2] Impact on the money market : Market analysis shows that the "Belt and Road " summit has injected a dose of strengthening agent to the RMB. Youkai Foreign Exchange pointed out that at 10 : 00 a.m., according to the data of China Foreign Exchange Trading Center, the reference exchange rate of RMB against the U.S. dollar was 6.8928, and the offshore RMB rose again. The dollar refreshed to 6.8857 against the offshore RMB for three weeks, a decline of about $0.09 \%$. The People ' s Bank of China set a daily intermediate price of RMB against the United States dollar, only allowing the RMB to fluctuate within the range of $2 \%$. USK Youkai Group said, In recent years, the fluctuation of $\mathrm{RMB}$ intermediate price is quite limited. The RMB intermediate price rose $0.15 \%$ on Friday, the largest increase since late April. However, at the beginning of 2016, the reason why the outside world focused on the RMB was that the central bank of China led the RMB to decline. [3] Impact on the foreign exchange market : Hong Kong market RMB short-term borrowing costs surge, making the cost of short RMB greatly increased. Analysts often attribute the huge increase in offshore RMB borrowing costs to the Central Bank of China. Therefore, although the RMB in the offshore market is stronger, this is not because investors have changed their views on the RMB. The biggest effect after World War II is to promote the opening up of the world market. Developing countries have achieved rapid development through the participation of this open market. However, not all countries can get great benefits. Therefore, it is necessary to help these developing countries to improve the basic development conditions and improve them under the conditions of opening up. Without solving this problem, many of them cannot develop, so they are both for us and for everyone. This is a new concept of development that is intended to help developing countries improve basic conditions and not simply emphasize such market openness. With the Belt and Road, we quickly promoted the AIIB, the new development bank, the BRICS, the establishment of the Silk Road Fund and so on.

\section{CHINA AND OTHER COUNTRIES AROUND THE WORLD ARE FACING STRATEGIC ADJUSTMENTS TO SUCH PROBLEMS.}

China has effectively promoted multilateral diplomacy, promoted the reform of the international system and the global governance system, and also increased the representation and discourse power of developing countries. With regard to global imbalances, excess liquidity and currency crises, the US has historically adjusted imbalances through a devaluation of the dollar, a fall in the dollar 's rate of appreciation and a rise in the dollar 's interest rate, triggering world-wide capital flows in the opposite direction and triggering currency crises in emerging economies. Faced with possible adjustments to global imbalances, China 's exchange rate and monetary policies should remain cautious and flexible. [4]

\section{CHINA' S MARKET CONSTRAINTS IN OVERSEAS INVESTMENT ALONG THE BELT AND ROAD AND THE REASONS FOR THIS PHENOMENON}

Market constraints : Chinese enterprises have also exposed many problems in economic cooperation in some regions due to different overseas business environments. Their participation in bilateral or multilateral cooperation overseas is also faced with regional political and cultural complexity. For example, the problem of labor relations has become a key factor restricting Chinese enterprises in overseas policy operation. Some labor disputes, the strike scale is huge, the number of employees involved is large, the strike time is long, and even evolved into violent incidents, the impact is very bad. Such as McDonald ' $\mathrm{s}$, KFC is suspected of illegal employment. On March 28,2007, 《 New Express》 newspaper reported that one journalist and three interns in the newspaper spent two months undercovering McDonald ' $\mathrm{s}$, KFC and winners respectively, and earned less than the minimum standard of part-time employment stipulated in the city. [1] The US “ 《New York Times》” published a paper saying that Chinese glass manufacturer Fuyao Group was facing the trade union movement initiated by the All-American Federation of Automobile Workers. This incident did not surprise me. Whether it is for overseas direct investment, or simple export of foreign goods and engineering contracting, whether it is in developed countries and regions such as the United States and Europe, or in developing countries and regions such as Peru, Zambia and Cambodia, the friction between labor and capital relations has long become one of the biggest tests for Chinese enterprises overseas. For high risk countries and regions as far as possible to replace investment in factory production with sales to meet the reasonable 
requirements of enterprise employees o These are necessary lessons to deal with overseas labor relations. But the primary task is to correct the name for the Chinese model, occupy the theoretical and moral commanding heights, otherwise it is impossible to get rid of passive. At the same time, it also caused serious problems such as short-term labor contracts, unemployment of older workers in foreign enterprises and compensation after unemployment. The main reasons for this phenomenon are : 1.Some international companies own many problems, management level needs to be further improved, lack of experience in international management, enterprise management consciousness is still completely changed, not adapt to the international management system. Thus caused by the labor problems caused by many disputes. 2.Chinese enterprises have not yet perfect the welfare mechanism, in many overseas Chinese enterprises, some employees receive wages lower than the wages of local peers in other enterprises, but also does not have a sound welfare system.

3.The multinational enterprises do not safeguard the interests of employees. Some enterprises increase employees ' working hours without permission without pay. At the same time, it also did not give employees working abroad from China a good living and working environment. At the same time, it also did not give employees working abroad from China a good living and working environment. There are also cases of child labor, with at least 264 million children worldwide, with an average age of 5-14 years, working full-time or parttime. Almost half of the world 's 12.3 million forced laborers are children.[5]

\section{PROBLEMS AND COUNTERMEASURES OF CHINA'S B \& R MARKET SERVICE SYSTEM}

China 's market service system needs to be improved and perfected. China ' $s$ multinational enterprises have small investment scale, lack of core technology, low R \& $\mathrm{D}$ ability and lack of effective cultural integration. The data show that Chinese overseas investment continued to decline in 2019, with industry-wide foreign direct investment and announced overseas mergers and acquisitions falling $9.8 \%$ and $31 \%$ respectively. Driven by the " Belt and Road " initiative, Asia has jumped into the most popular area of overseas mergers and acquisitions by Chinese companies, with growth recorded adversely. Overseas TMT, consumer goods, electricity and public utilities and other industry standards continue to be favored by Chinese enterprises. Foreign contracted projects continued to develop steadily, with an increase of $7.6 \%$ in 2019 . [ 2 ] Countermeasures : 1. Establishing and improving the political system. Timely grasp the development and changes of foreign enterprises, strengthen the detection of the effect of foreign investment.
2. Adjust diversification of foreign investment. Establish information services mechanisms for subregional trade and investment, achieve information sharing and facilitate the formation of free trade zones.

3. Establish and improve market service systems. Provide enterprises with overseas business environment, policy environment, opportunities for partners, credit and other information projects.

4. Enhancing core competitiveness. It can be technology, sales ability, marketing strategy, organizational culture and business philosophy. In short, only to build a core competitiveness to adapt to international competition can really go abroad, based on the international market.

\section{CHINA' S SECURITY PROBLEMS AND COUNTERMEASURES IN THE BELT AND ROAD INITIATIVE}

First, security risks such as regional turmoil, war and terrorism will become the top priority for Chinese enterprises to move towards the belt and road. compared with America 's global strategy, china 's one belt one road strategy is characterized by its emphasis on economic and cultural exchanges rather than military hegemony. in the recent period, china 's military outgoing remains a highly sensitive and cautious issue, and unless faced with extreme situations such as the civil war in Libya and the Yemen crisis, the security problems of our enterprises will remain largely resolved by non-military means. correspondingly, in recent years, the security situation of some countries on the belt and road has deteriorated significantly. in recent years, the influence of Islamic radical forces in the Pan-islamic region has been significantly enhanced. radical forces such as Islamic countries are spreading from Syria and Iraq to gulf and central Asian countries. following the withdrawal of united states troops from Afghanistan, how security gaps in central Asia will be filled and how the security situation in Pakistan, Tajikistan and Uzbekistan will change is a matter of concern. china ' $s$ enterprises engaged in pipeline construction, railway construction has been fully considered in the planning and design of security needs, and as far as possible to avoid unstable areas ( in unstable and unsafe countries to find a relatively stable and safe small area, this approach is known as oasis tactics ), but this is still based on the central government of Pakistan and other countries have full ruling power. once the overall security situation of these countries deteriorates, the effectiveness of oasis tactics will be problematic.

China needs five measures to respond. first, strengthen risk assessment of the security situation, political trends, legal characteristics and financial situation of countries along the belt and road. second, strengthen safety protection measures for Chinese 
enterprises and companies operating in countries along the route, while hiring local security company personnel to perform security tasks. third, strengthen the training of personnel to countries along the line, avoid conflicts with the local people, cultivate friendship with the people. fourthly, we should steadily promote the construction of the belt and road initiative, and constantly learn from and promote it under the circumstances of avoiding security and legal risks. fifth, play the leading role of enterprises, in the case of ensuring profitability to meet some of the other 's profit requirements. Finally, The political system, religious culture, economic foundation and infrastructure conditions of the countries along the 'Belt and Road ' are quite different, and they are highly dependent on Europe and the United States economically and culturally. The identity of the system and mode of China ' $s$ output is not strong. Chinese enterprises want to substantively get rid of the passive situation in international business expansion, they need to upgrade from ' internationalization ' to ' internationalization ' as soon as possible, from ' extensive participation in international standard formulation ' to ' mastery of discourse power '. Chinese enterprises entering the deep water area of overseas markets are bound to face a large number of sudden risks. Whether it is uncontrollable political and financial risks, or changes in regional investment environment and internal management problems of enterprises, they will hinder the internationalization of Chinese enterprises.

The construction of ' The Belt and Road ' is at the key node of comprehensive promotion. The concept of ' The Belt and Road ' is common development, and the goal is win-win cooperation. It is not the head of a Chinese cake or cake, but along the countries together to make cake bigger, cake together. In this process, we should not only make contributions to the international community by strengthening cooperation between all parties, but also promote domestic reform and serve domestic development by expanding foreign cooperation. We should combine China 's own development needs with the needs of international cooperation, especially to fully reflect the consensus of international cooperation. Industry insiders believe that the "Belt and Road " should be based on international and domestic changes, timely adjustment measures. Liu Huaqin, a researcher at the Research Institute of the Ministry of Commerce, told China Economic Reporter : ' We should fully assess the risks of investors, consider investment and earnings, and share consultations and co-construction. For example, Central Asian countries, financial markets are underdeveloped, many need Chinese loans for ' blood transfusion, ' but investment is not bottom. In order to change the financing mode, PPP mode may be adopted.

According to the principle of "enterprise subject, market operation, international practice, and government guidance," the Ministry of Commerce will continue to support domestic capable and qualified enterprises to carry out truly compliant foreign investment activities, participate in the joint construction of the Belt and Road Initiative, carry out international capacity cooperation, and integrate into the global industrial chain and value chain. At the same time, the improvement of foreign investment in the long-term system construction and short-term camera control combined to promote the convenience of foreign investment at the same time to prevent the risk of foreign investment, improve and standardize the market order, further optimize the direction of foreign investment, highlighting the real economy and emerging industry orientation, promote the healthy and orderly development of foreign investment, to promote the transformation and upgrading of domestic economy, deepen the mutual benefit cooperation between China and the world to make greater and more sustainable contribution.

\section{CONCLUSION}

Chinese enterprises and citizens must get rid of excessive dependence on the state, enhance the ability of organizations and protect themselves in the process of going out. On the one hand, citizens and enterprises "going out" should, under the coordination of relevant departments, build organizations, enhance their own security forces and improve their negotiating ability with the local society. On the other hand, Chinese society should also explore and withdraw from overseas private security services with Chinese characteristics as soon as possible, so that ' going out ' enterprises and individuals can trust the market to obtain security. Although Chinese enterprises are facing many uncertain risks in joining the Belt and Road Initiative, some problems have been or are being solved gradually with the introduction of some targeted support policies.

\section{REFERENCES}

[1] On March 28, 2007, 《New Express》

[2] New Thoughts on Risk Prevention and Control of Overseas Investment in the Belt and Road Initiative from September 20 to 14

[3] 2014 Youkai Foreign Exchange Group

[4] On the Belt and Road Overseas Investment's Impacts on the Global Finance, Market Constraints and Hostile Risk Management BAO Jian-yun 2007

[5] International Labor Organization

[6] National Bureau of Statistics On October 21,2014 